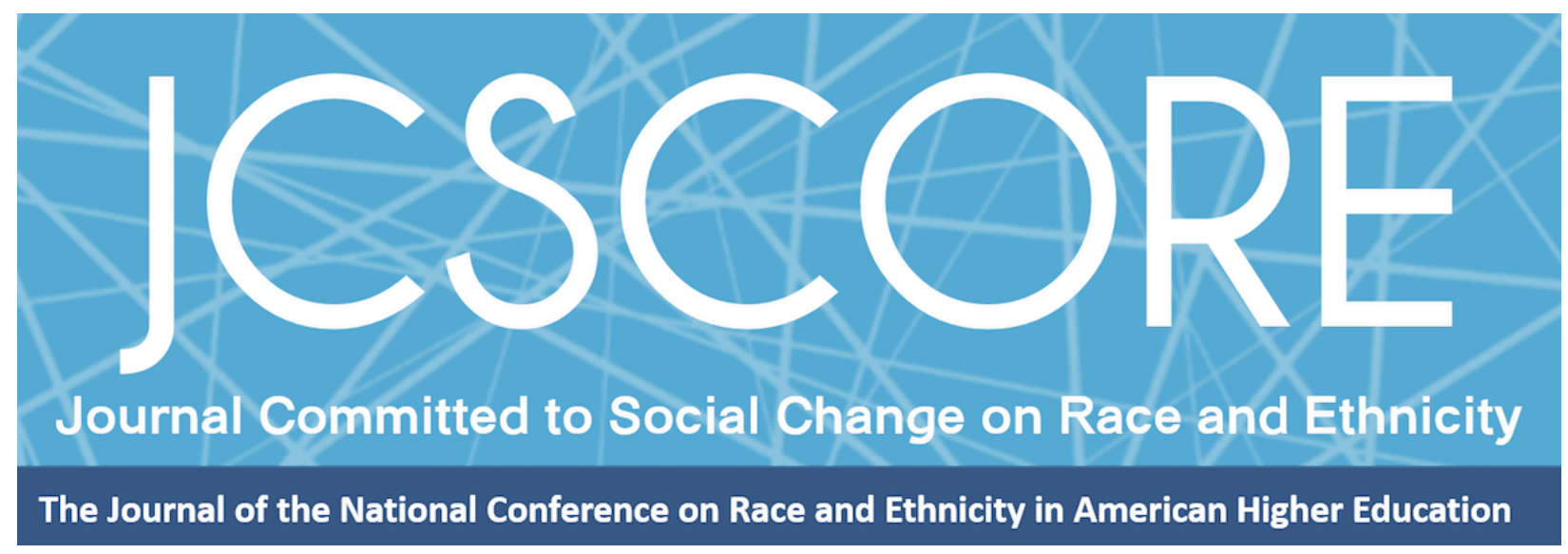

\title{
CONTROLLING IMAGES: INSTITUTIONAL STEREOTYPES OF ENGAGEMENT OF LOW-INCOME FAMILIES, FIRST-GENERATION FAMILIES, AND FAMILIES OF COLOR
}

Delma Ramos

University of Denver

Judy Marquez Kiyama

University of Denver

Casandra E. Harper

University of Missouri

Journal Committed to Social Change on Race and Ethnicity

Volume 3, Issue 1 | 2017

Copyright (C 2017 Board of Regents of The University of Oklahoma on behalf of the Southwest Center for Human Relations Studies.

Permission of the Publisher is required for resale or distribution and for all derivative works, including compilations and translations. Quoting small sections of text is allowed as long as there is appropriate attribution. 


\title{
Controlling Images: Institutional Stereotypes of Engagement of Low- Income Families, First-Generation Families, and Families of Color
}

\author{
Delma Ramos \\ University of Denver \\ Judy Marquez Kiyama \\ University of Denver \\ Casandra E. Harper \\ University of Missouri
}

This multiple case study examines how higher education institutions utilize controlling images to establish guidelines of family engagement, including that of first-generation families, low-income families, and/or families of color. Family engagement is limited to the extent to which it aligns with controlling images that paint families as overly involved or as uninterested, disengaged, and absent from the college experience of their children. This research contributes to our understanding of institutional responsibility when engaging diverse families. By utilizing controlling images as a framework, the article critically examines the stereotypes ascribed to families that shape their engagement experiences. Institutional, practice-based, and research implications are offered.

Research on parental and family involvement is largely limited to exploring the participation of families in K-12 (Auerbach, 2004; Ishimaru, Torres, Salvador, Lott, Cameron Williams, \& Tran, 2016; Jun \& Coylar, 2002; Tierney, 2002), although research within a higher education context is growing (Kiyama \& Harper, 2015; Wartman \& Savage, 2008). More specifically, exploration of the involvement of firstgeneration families, low-income families, and families of color is limited with few studies examining family involvement in college readiness with a focus on school-family partnerships, perceptions of college enrollment as informed by race and class, and assets for college readiness found within their households (Auerbach, 2004; Holcomb- 
Journal Committed to Social Change on Race and Ethnicity | 2017

McCoy, 2010; Jun \& Coylar, 2002; Kiyama \& Harper, 2015; Tierney, 2002; Yamamura, Martinez, \& Saenz, 2010; Yosso, 2005).

In considering parental and family involvement in higher education, much of the research has centered on a dominant narrative that describes family involvement as detrimental to the college transition, experience, self-efficacy, competence, and wellbeing of students (LeMoyne \& Buchanan; 2011; Smith \& Zhang, 2010; Lopez Turley, Desmond \& Bruch, 2014; Reed, Duncan, Lucier-Greer, Fixelle, \& Ferraro, 2016; Ulutas \& Aksoy, 2014), or that distance and separation can facilitate college adjustment (Sarigiani, Trumbell, \& Camarena, 2013). Indeed, much of the extant literature has described family involvement as limiting students' independence and self-sufficiency (Rostad, Medina, \& Hurtig-Crosby, 2014; Lopez Turley, Desmond, \& Bruch, 2010, Carney-Hall, 2008; Taub, 2008). Some exceptions exist, where parent and family involvement has been associated with positive student outcomes. For example, more frequent electronic contact was related to increased levels of attachment with mothers, which was also associated with adjustment to college (Sarigiani, Trumbell, \& Camarena, 2013). Frequent student to parent communication and parental intervention on the student's behalf were correlated with increased levels of students' self-reported "engagement, deep learning and greater educational gains," although these students were also more likely to struggle academically (NSSE, 2007, p. 25). Parental involvement has also been correlated with mostly positive student outcomes, whereas parental contact was not (Harper, Sax, \& Wolf, 2012). The role of parental involvement and contact is even more complicated when considering differences in associations by race, gender, and social class (Harper, Sax, \& Wolf, 2012). For instance, Kwon, Yoo, 
Journal Committed to Social Change on Race and Ethnicity | 2017

and Gagne (2017) explored the perceptions of Korean American college students on helicopter parenting and its impact on their development and experience in college. Authors found that students perceived negative effects on helicopter parenting including disruption of healthy development by restricting freedom and student ability to make their own decisions through authoritarian parental practices. In contrast, around $80 \%$ of study participants $(n=33)$ also acknowledged the benevolent intentions of parents who are overinvolved. That is, students conceptualized helicopter parenting as a way for parents to protect their children from foreseeable harm and to show their love. Students also spoke about other benefits including doing well in academics and career preparation and making healthy choices.

Attention to the role of family involvement among parents and families of color remains underdeveloped (Bonilla-Silva, 2003; Kiyama \& Harper, 2015; Lowe, Byron, Ferry, \& Garcia, 2013; Schofield, 2003. Furthermore, literature on family involvement and engagement of low-income families, first generation families, and families of color is limited and has just recently begun to positively reflect the roles of these families in the college experience and challenge deficit frameworks (Kiyama \& Harper, in press; McCulloh, 2016). The focus of this study is to draw upon the controlling images framework (Collins, 1990) to determine the ways in which dominant ideologies inform the level, form, and frequency of family engagement in college for diverse groups of parents and families. We call attention to the institutional constructions and assumptions of family engagement as understood through a controlling images lens. The research questions guiding this study are: How do institutions of higher education prescribe the engagement of first-generation families, low-income families, and/or families of color? 
Journal Committed to Social Change on Race and Ethnicity | 2017

What images are evoked to define, limit, or encourage the engagement of low-income families, first-generation families, and/or families of color on college campuses?

\section{Literature Review}

Research addressing the positive contributions diverse families offer, in the form of involvement and engagement for their college-aged children, is emerging (see Kiyama \& Harper, 2015). Our aim is to explore the literature that examines the evolution from family involvement to engagement in college. Important in our work is the intentional use of the term engagement, and its representation as a more culturally inclusive way of describing the contributions and roles that first-generation families, lowincome families, and families of color offer, which differ based on cultural, historical, and social orientations (Calabrese Barton, Drake, Perez, St. Louis, \& George, 2004; Kiyama \& Harper, 2015). This broader terminology also encompasses the multiple ways in which families frame their engagement. Specifically, "involvement has been used to describe the specific things that parents do, while engagement also includes parents' orientations to the world and how those orientations frame the things they do" (Carreón, Drake, \& Calabrese Barton, 2005, p. 469). While we draw on engagement to frame our work, we do use involvement when citing specific literature that uses the term. It is with this framing in mind that we turn to the ways in which we have come to understand the roles that families play at the college level.

\section{Family Engagement in College}

Literature on family involvement at the college level largely examines the association between parental support and college aspirations (Auerbach, 2004, Berzin, 2010; Choi, Tekleselassie, \& Mallery, 2013; Jun \& Colyar, 2002; Kiyama, 2010; Tierney, 
Journal Committed to Social Change on Race and Ethnicity | 2017

2002), where more parental involvement during earlier years is associated with stronger postsecondary academic aspiration development among youth, which may foster higher rates of college enrollment (Choi, et al., 2013; Tierney \& Auerbach, 2004). While parent and family involvement during pre-collegiate years is encouraged and widely examined in the literature (Auerbach, 2004, Berzin, 2010; Choi et al., 2013; Jun \& Colyar, 2002; Kiyama \& Harper, 2015; Tierney, 2002), research on involvement and engagement at the college level does not offer a clear picture of the contributions of the roles parents and families play in the college experience of their children. Additionally, research on parent and family engagement can be reductive, characterizing involvement into a dichotomy of either positive (Garriott et al., 2010; Kolkhorst, Yazedjian, \& Toews, 2010; Melendez \& Melendez, 2010; Parade, Leerkes, \& Blankson, 2010; Raque-Bogdan, Klingman, Martin, \& Lucas, 2013; Serido, Shim, Mishra, \& Tang, 2010) or negative (Carney-Hall, 2008; LeMoyne \& Buchanan, 2011; Lopez Turley, Desmond \& Brunch, 2010; Taub, 2008).

Among the research finding positive associations of parent and family involvement in the college experience of their children, the supportive role parents and families play has been primarily associated with students' positive social adjustment to college (Garriot, et al., 2010; Kolkhorst et al., 2010; Parade, et al., 2010; Sarigiani, et al., 2013), financial literacy (Serido, et al., 2010), parental pressures and expectations (Furry \& Sy, 2015; Kwon, Yoo, and Gagne, 2017), sense of self-efficacy to address challenges (Raque-Bogdan et al., 2013), and academic achievement (Melendez \& Melendez, 2010). Sax and Weintraub (2014) studied students' emotional well-being during the first year of college and found that emotional well-being was strengthened 
when parents were viewed as "supportive, helpful, nonintrusive, and uncritical" (p. 122123). When students feel securely attached to their parents during the first year of college, they often develop friendships that are also positive (Parade et al., 2010). Parental involvement has also been depicted positively in providing financial support, helping with student safety and mental health issues, and managing roommate issues (Carney-Hall, 2008). Furthermore, parent and family involvement can support college students holistically in critical aspects of their experience such as their personal and social development, academic success, and their emotional and social transition to college (Kiyama \& Harper, 2015). Therefore, this emerging research is evidence that parent and family support is associated with students' developmental, social, emotional, and academic outcomes (Kolkhorst et al., 2010; Mattanah et al., 2011).

In contrast, there is research that characterizes parent and family involvement in college less favorably and often from a deficit lens. The predominant stereotypes about the involvement of today's parents of college students depicts them as undesirable and negative (Carney-Hall, 2008; Taub, 2008). More specifically, elevated levels of parent and family involvement have been linked to emotional and psychological difficulties among college students (LeMoyne \& Buchanan, 2011; Kwon, Yoo, and Gagne, 2017; Reed et al., 2016; Ulutas \& Aksoy, 2014). The college enrollment options may be more limited among first-generation and students of color with strong ties to their parents and who do not want to be physically distant from family (Lopez Turley et al., 2010). Such findings may inadvertently highlight negative implications like the inflexibility to move away for college rather than the cultural resources found in families when students attend college in close proximity to their families (Sapp, Kiyama, \& Dache-Gerbino, 
Journal Committed to Social Change on Race and Ethnicity | 2017

2016). Smith and Zhang (2010) concluded that first-generation college students had less family support during their transition to college and therefore were at disadvantage compared to second-generation students. Perhaps the most pervasive negative stereotype surrounding parent involvement is the notion of helicopter parents, also termed bulldozers, black hawk parents, and kamikaze parents (Kiyama \& Harper, in press; Wartman \& Savage, 2008). These terms suggest that parents' role is overly hovering, extreme, and potentially harmful to students' development (Kiyama \& Harper, in press; Kwon, Yoo, \& Gagne, 2017; Reed et al., 2016; Taylor, 2006. More often than not, underrepresented families are missing or portrayed as less involved, harmful, and less resourceful for their college-aged children. For this reason, we position this article as a response to the call that parent and family engagement literature examine differences by student race, gender, and socioeconomic class (McCarron \& Inkelas, 2006; Sax \& Wartman, 2010; Kiyama \& Harper, in press) and by first-generation status (Choy, Horn, Nuñez, \& Chen, 2000; Kiyama, Harper, \& Ramos, in press).

\section{Conceptual Framework}

We draw upon the controlling images conceptual framework proposed by Collins (1990) as part of her work in Black Feminist Thought. Controlling images are stereotypical images that portray African American women as mammies, matriarchs, welfare recipients, and hot mamas. Controlling images result from the domination and oppression of these women. Collins argues that these images were created to make racism, sexism, and poverty essential elements of the everyday life of these women. Collins adds that these images remain intact within society even after women are able to overcome the implications of racism, sexism, and poverty. Controlling images have 
been embraced by dominant groups to the extent that they have been used to inform policy development and as justification for oppressive discriminatory practices against African American women (Collins, 1990). These images or "props," as Collins (2013, p. 4-5) has also described them, are used to illuminate and maintain dominant narratives of those in dominant positions. The images and props are stereotypes about race/ethnicity, class, gender, and sexual exploitation (Collins, 2013).

Another element of these controlling images is that they assist those in power with defining the social and economic boundaries of their oppressive society by perpetuating and othering the disadvantaged. The other-those who do not belong to the dominant group—are negatively positioned to support the membership and sense of belonging of those in the dominant group. The controlling elements of these images are only effective at keeping marginalized groups marginalized when objectification is in place. That is, domination helps objectify the subordinated group, by attempting to strip the power of the subordinated group to define their own reality (Collins, 1990). Consequently, when considering systems of power, ideas and images about nondominant groups then "permeate the social structure and become hegemonic," normalized, and accepted (Collins, 2013, p. 32). Thus, the use of controlling images work to create a symbolic dimension of oppression (Collins, 2013).

Applying this conceptual framework to the college engagement of first-generation families, low-income families and/or families of color allows us to deconstruct the ways in which systems of domination define their involvement and engagement on college campuses. Similar to the African American women in Collins' (1990) work, firstgeneration families, low-income families, and families of color are oppressed as they 
find themselves trapped between systems of race, class, and dominant forms of knowledge. Moreover, their engagement in college is mediated by oppressive practices fueled by domination of those who are in power as they prescribe their engagement based on the controlling images that have been constructed for them. Furthermore, these images become the object by which deficit perspectives on diverse families are perpetuated, a clear portrayal of how those who are in power define the social and economic boundaries of oppressive campus environments, which in turn justify practices that limit and manage the engagement of these families.

\section{Methodology}

In this paper, we utilize a multiple case study (Yin, 2003) research design. This multiple case study is part of a larger study in which we examine the experiences and roles of parents and families during the college transition process. Within this larger study, we investigate institutional practices and commitment to engaging low-income families, first-generation families, and/or families of color. The larger study consists of three phases: 1) a descriptive content analysis of orientation programs across the country, 2) a multiple case study of parent and family orientation programs including program observations and interviews with staff, and 3) a series of interviews with parents and families during students' first year of college. It is from the second phase of this larger study that we focus this article.

By employing a multiple case study design, we allow for more than one case to be examined. In this study, each institution represents a case, allowing for analysis within and across the different institutions. For this paper, a cross-case analysis was 
Journal Committed to Social Change on Race and Ethnicity | 2017

most appropriate. The sample is comprised of nine diverse institutions, each of which offer orientation and/or year-long programming for parents and family members.

\section{Data Collection}

Data were collected from Summer 2014 - Spring 2016. Case study research calls for multiple points of data to be collected (Yin, 2003). Therefore, three points of data were collected for each institutional case. First, members of the research team attended a one to two-day parent/family orientation session at each institution. In the case of the open-access institution, we attended two orientations - the English and Spanish orientations. We assumed the role of participant observers and took detailed observation notes about the types of programs and sessions offered to parents and families. We also took notes on the ways in which families were communicated with and the means through which these messages were delivered. Second, we conducted semistructured interviews with one to two orientation or parent/family programming staff at the institutions. Third, we collected documents related to communication with and for parent/family members from each institution. In total, we conducted over 200 hours of observations, interviewed 16 parent / family staff members, and collected documents ranging from promotional orientation materials to orientation programs and booklets to post-orientation assessment reports. Findings from this article focus largely on interview and observation data.

Institutions. The nine institutions included in this study were chosen through multiple approaches. First, after national conference presentations about the study, some staff members approached us with an interest in participating. Second, we intentionally sampled institutions that offered year-long parent and family programming 
and Spanish orientations, in addition to the parent and family sessions offered during

orientation. And third, one institution was noted by other participant institutions as an

exemplary parent/family orientation program, so we invited that institution to participate.

Below are brief institution profiles:

Table 1: Institution Profiles

Institution

Summary

Institution 1:

Public Flagship, 4-year and above, more selective, high undergraduate enrollment, very high research activity university. Its first-year enrollment totaled 6,221 in Fall 2015, the largest, most diverse, and most qualified first-year class in its history.

Institution 2: $\quad$ Public, 4-year and above, selective, high undergraduate enrollment, very high research activity university. This institution's total undergraduate enrollment exceeded 32,000 in 2014.

Institution 3: $\quad$ Public, 4-year and above, selective, high undergraduate enrollment, very high research activity, primarily residential university. Total first-year enrollment in 2014 exceeding 4,000.

Institution 4:

Public, 4-year and above, selective, primarily nonresidential baccalaureate college. Total undergraduate population in Fall 2014 exceeded 20,000. Included both Spanish and English orientations.

Institution 5: $\quad$ Private not for profit, 4-year or above, more selective, primarily residential, high research activity university. This university's total enrollment Fall 2014 exceeded 11,000 .

Institution 6: $\quad$ Private not for profit, 4-year or above, more selective, small four-year, highly residential, baccalaureate college (Arts \& Sciences). There was a total of 2000 students enrolled at this institution in Fall 2015.

Institution 7: $\quad$ Public Land Grant, 4-year and above, selective with very high research activity, total enrollment over 35,000 in Fall 2015.

Institution 8: $\quad$ Religiously-based, private institution; 2-year and above. Moderately selective baccalaureate college with some master's degrees offered. Approximately 2,000 students on campus in Fall 2015.

Institution 9: $\quad$ Private liberal arts institution, 4-year and above. Selective baccalaureate college. Total enrollment under 1,000 students in Fall 2015.

Participants. Within six of the institutions, we interviewed at least one orientation staff member and one parent/family staff member. Recruitment of staff participants at 
Journal Committed to Social Change on Race and Ethnicity | 2017

the remaining three institutions is ongoing. Our goal was to understand how families were perceived, engaged, and communicated with from the point of orientation through academic year programming aimed at parents and families. We were also directed to staff who oversaw programs that regularly engaged with parents and families (e.g., firstgeneration student programming). In total, we interviewed seven orientation staff members (coordinator, assistant director, and director levels), six parent and family staff members (assistant director and director levels), and three staff members who oversaw academic year family engagement programs. Participants included 12 women and 4 men; their time at their respective institutions ranged from 2 to over 15 years. All participants, institutions, and institutional mascots have been given pseudonyms.

\section{Data Analysis}

Our framework of controlling images guided the analysis for this paper. Specifically, we drew upon the analysis strategy that Yin (2003) describes as "relying on theoretical propositions" (p. 111). Within this strategy, the design of the study is informed by theoretical propositions, in this case the assertions made within a controlling images framework, in addition to the literature we reviewed, and our guiding research questions.

The first step of our analysis process included uploading all data into NVivo10 software. Then, all members of a five-member research team, including doctoral students and one of the principal investigators, read the same two interview transcripts out of the full 16 and all of the observation notes to begin generating a list of codes, informed by our framework and existing literature, to upload into NVivo. This also allowed for inter-coder agreement and consistency in preliminary findings (Merriam, 
Journal Committed to Social Change on Race and Ethnicity | 2017

1998). Then two members were assigned to each institutional case and further analyzed each form of data in NVivo. As an example, we began with a broad code like diverse families (coded 72 times) and then moved into more specific codes within, like types of programming (coded 26 times). This helped us to narrow in on the specific programming that was available for low-income families, first-generation families, and families of color. We followed similar coding procedures for other broad codes (e.g. assumptions, inclusive excellence or social consciousness terminology). We then moved into a more specific analysis informed by our framework of controlling images. An analytical grouping informed by controlling images was then organized into subcategories. This grouping included assumptions made by the institution about letting go, the college transition process, and assumptions of involvement for diverse families of color. We worked to offer a definition and attach data points (e.g., quotes, observation notes) to specific images. For instance, our reliance on theoretical propositions led us to presume that negative images were constructed by institutions about diverse families. This theoretical orientation helped to focus attention on certain data. For example, we share the following in the findings section of the paper:

Grace, an administrator who oversaw orientation at a private institution, shared that during an orientation a parent questioned why diverse families were not present during orientation asking, "American ethnic minority [students] make up $20 \%$ of [the] incoming class, why don't their parents care to come to campus? Why don't they care?" In response to this question, Grace, explained that many families cannot take the time off work to attend multiple-day orientation sessions.

This particular point of data helped us to explain the "how" behind the development of these negative images about families. The utility of "relying on theoretical propositions" is that the case study is organized around the framework while offering room to examine "alternative explanations" to construction of the images (Yin, 2003, pp. 111-112). 
Journal Committed to Social Change on Race and Ethnicity | 2017

\section{Trustworthiness}

In an effort to establish trustworthiness, we drew on multiple techniques. Our research team consists of two teams at two institutions. While the team at the University 1 took the lead on this phase of the research, we utilized our colleagues at the University 2 to provide an "external check of the research process" (Creswell, 2007, p. 208). We also drew on peer debriefing as a validating strategy. Peer debriefing occurred through regular Skype research meetings and writing retreats where we discussed data collection and analysis procedures, emerging themes, and preliminary findings.

We worked to establish a sense of trust and rapport with participants and spent time answering participants' questions and inquiries about the project before any data collection began. Because of our focus on first-generation families, low income families, and families of color, some participants wanted to ensure that we were not entering into the study with pre-existing stereotypes of these groups and that we were going to be respectful of families' experiences. We spent time sharing our asset-based paradigms for conducting research, particularly with diverse populations. These early conversations helped to establish an important element of trust. Finally, in addition to observation notes, research team members were asked to write memos as part of the data collection process (Charmaz, 2006). In the memos we captured initial thoughts, concerns, biases, and questions about the data collected. Although we did not code the memos for themes, we did use them as a check-point for working through researcher questions, assumptions, and reflections. 
Journal Committed to Social Change on Race and Ethnicity | 2017

\section{Findings}

Our findings reveal that institutional constructions of controlling images of diverse families uncover assertions made about family engagement in students' college experiences. As these families are packaged in controlling images such as the everabsent family and the malleable family, their engagement and motivations are in some ways constrained and misinterpreted. The findings also supported the emergence of an asset-based image of families, the cornerstone family. Below, we present each of these family images and draw on the provided descriptions to interpret each of the three images. First, the ever-absent family is characterized by images of families habitually removed from the college involvement picture as informed by assumptions and misconceptions that portray diverse families as lacking college knowledge. The engagement of these families is devalued and perceived as non-existent and not critical. Second, the malleable family is characterized by images of families that can be molded to be involved according to the rules of those in power. Families within this image are shaped to be present when desired and subsequently gone when those within positions of power deem it adequate. Third, the cornerstone family is characterized by images of families that are more inclusive of diverse forms of engagement from low-income families, first-generation families, and families of color. Family is recognized as key in the college experience as it represents invaluable support for student success. Families are welcomed into institutions in multiple ways.

\section{The ever-absent family}

At least some staff at all institutional sites shared common views of firstgeneration families, low-income families, and/or families of color. These groups were 
described as disengaged and reluctant to become involved in the college experiences of their children. As stated by Sussane, a program administrator at a large public university, "First generation, working class families are not involved, they have no idea, [and] expect their student to handle their [own] business." Sussane's controlling image of first-generation, low-income families consisted of a hands-off approach in which parents were ignorant of college-going processes and were uninvolved in students' decisions in college. Likewise, Diana, a staff member at a large public university commented:

First-generation parents are very different than non-first-generation parents too. It's interesting because the most contact I have tends to be with the most entitled parents. They'll call and want stuff done with their kids.

Diana's comment suggests that first-generation parents generally are not the family members who call on a regular basis. This perception was mirrored by Gully, who works at a public flagship:

You know, the first thing that came to my mind was more dealing with international students than domestic students who might be of a particular ethnic group or a particular identity. Honestly, that's not something we get a lot of questions about. Now I'm not saying that parents of students who come from a particular - have a particular identity aren't asking questions, but they don't pop up in our office that often.

Throughout Gully's interview, there was a consistent message of not working with families from first-generation, low-income, and backgrounds of color. Whether that is because these families did not "pop up" or were not actively engaged by the institution, it continues to perpetuate the image that they are missing or absent from the picture. This assumption about parents represents the image of the ever-absent family, a family who is automatically removed from the college involvement picture because of 
Journal Committed to Social Change on Race and Ethnicity | 2017

misconceptions that portray first-generation and families of color as lacking college knowledge and uninterested in college engagement.

Ali, a staff member at a public university asserted that "first-generation parents are reluctant to come to campus [and] are not complaining about not being part of advising." In narrating what staff had heard from other parents, university personnel shared that low-income and first-generation families "did not care" enough to attend orientation programming.

In one particular instance, a director of parent relations at a public university stated that campus personnel do not hear from "parents from [this] particular group," referencing first-generation and low-income families. Grace, an administrator who oversaw orientation at a private institution, shared that during an orientation a parent questioned why diverse families were not present during orientation asking, "American ethnic minority [students] make up $20 \%$ of [the] incoming class, why don't their parents care to come to campus? Why don't they care?" In response to this question, Grace, explained that many families cannot take the time off work to attend multiple-day orientation sessions. Although Grace was familiar with the barriers posed to low-income and families of color in particular, her institution's orientation spanned multiple days and may have required families to travel, take time off work and possibly incur other expenses. Thus, although likely unintentional, the structuring of orientation sessions is contributing to the image of the ever-absent family and perpetuating stereotypes of disinterest. Furthermore, what seems to be interpreted by staff as not caring, reluctance to come to campus, or not complaining, could instead be understood as missing 
Journal Committed to Social Change on Race and Ethnicity | 2017

information on the part of first-generation families with respect to the various engagement they can have with their college-aged children.

Advice was offered and observed during all of the orientation sessions. One campus administrator shared with students the "ABCs of College:" ask questions, balance, and connect. She recommended that students connect with three people: a mentor, someone like yourself, and someone who is different. Yet, families as supportive members were not mentioned when encouraging students to step out of their comfort zone. Although the administrator may have assumed that existing relationships would play an ongoing role, families remained absent from the conversation. The everabsent family image justifies and reinforces the lack of college programming for underrepresented families and normalizes current exclusive practices that discourage participation and ignore diverse families' key role in the transition and experience of underrepresented students in college.

\section{The malleable family}

In terms of prescriptive family involvement, public and private institutions also were consistent in messaging. Although staff spoke of valuing the engagement of parents, they set several limitations on this involvement. Engagement of these diverse families was structured in ways that assumed parents would take a secondary role in students' college experience. With few exceptions, the parent and family orientation sessions did not invite families to engage. Rather, families were invited to sit and listen, often listening for many hours with limited time for questions at the end of sessions.

The messages conveyed from staff about the time after students' initial transition to campus and parents' roles suggested that they wanted parents to encourage their 
children to become responsible and independent, and to take charge and ownership of their experience. As recorded in observation notes, "[Parents are asked to] get out of the way and let go; let [students] experience independence and accountability" (Private Institution). In some cases, this "letting go" was signaled by a designated time that families and students were to say their good-byes, suggesting a formal break-away from the family unit. This was reinforced by Adelle, who argued that "[parents should] encourage their students to avail themselves [of] services" and by Gayle who expected "parents [to] take the back seat." These messages were also emphasized in print materials. For instance, one private institution created an informative parent and family handbook with various resources and contact information. The content included messages around transition, independence, interventions, and saying good-bye. The engagement section of the handbook was focused entirely on student engagement with no mention of how family members might stay engaged with their sons and daughters after they began college.

These messages are reflective of what Ali, a staff member at a large, public institution referred to as a "majority model," noting:

The parent relations office is really open in saying anybody can contact us so they put that message out but the parenting model that they're putting forward is a majority model. It's one that says let your student make decisions for themselves, do a lot of letting go.

Ali's reference to a "majority model" implies that families who remain connected with their students and help students make decisions are not the families represented in the model the parent relations office espouses. Thus, there appears to be contradiction and possibly, confusion in the types of messages families are receiving from institutions. 
At one particular institution, a smart phone app for students and parents was introduced. Students were encouraged to "save people in the app who can help you," while parents were encouraged to use the app to reload meal plans, dining, and order food (Observation notes, Public University). Technology was also encouraged as a means to connect with institutions' academic year parent and family programming, noting Facebook and Twitter as a helpful informational tool. Technology poses an interesting outlet for family engagement. On one hand, institutions can utilize technology as a tool to facilitate communication with families in a timely manner. On the other hand, we question if this further contributes to the malleable family image, as engagement can be perceived to be restricted to apps (and reloading meal plans) or communication via social media.

On the more restrictive end, one institution welcomed family involvement only in severe crises, such as when their children experienced mental health issues or when they were missing. Another institution offered families a list of DOs and DON'Ts during the transition to college, which was both inclusive and exclusive of family engagement (Public Flagship Institution). The DOs included messages like, "Do let them follow their own dreams" and "Do let them make their own decisions," including a reminder that parents were not invited to academic registration sessions. Some of the DON'Ts included, "Don't make [students] your confidant" and "Resist the temptation to continually check on students."

Such suggestions, practices, and approaches created the controlling image of the malleable family, where involvement is molded according to the rules of those in power and where families can be present or excluded whenever those in charge deem it 
adequate. This controlling image is applicable to families from all backgrounds.

However, we caution that it may have a greater negative impact on underrepresented families, as prescriptions for involvement are a product of the historic deficit perspectives through which families are seen. Thus, underrepresented families become the object, molded by the dominant group. Their reality may be disconnected from their own preferences and dictated by authority figures, who also rely on this dynamic to maintain the status quo. The malleable family image ignores the importance of diverse and culturally responsive forms of family engagement in college.

\section{The cornerstone family}

In contrast, those who perceive family engagement as critical for the success of college students are challenging controlling images of diverse families. These changing views on family involvement foster the emergence of asset-focused images such as that of the cornerstone family. The cornerstone family is key in the college experience as it represents invaluable support for student success. In the words of our staff participants, "parents [and families] are part of the Bear family" (Vida \& Abe, Public Institution). This statement not only recognizes these groups as key players but as members of the campus family. Similar sentiments were expressed by Gayle who asserted that she did not "see the [orientation] program without [families]...especially for the types of students who are first-generation, who are nervous themselves about pursuing higher education. That support role is so critical." Sussane echoed this sentiment, acknowledging that "students don't come to campus alone; [They come with their families]."

The emergence of this image portrayed the highest dissonance between expectations for family engagement and next steps for institutional programming and 
involvement for families. Public and private institutions were equally, at least verbally, invested and interested in developing partnerships with families. At a Flagship Institution, our research team recorded in observation notes that one staff member in particular stressed that the institution worked for the parents and families. He encouraged families to come to him with any questions. Thus, some of the institutions expanded their awareness of students' complex support networks and shared ideas for engaging families during the orientation process. Marly, who helped oversee parent and family orientation at a previous institution as a graduate student, described a program she created where parents and students share their college transition experiences. She was hoping to implement the same programming at her current institution:

One piece I did, was intentional about, is we have parents who sit on a panel with the students. I founded that panel with my parents right before I graduated, and one of my parents, my dad, loved it. He got to share his story, but also it helps parents hear from other parents, and ask them questions about their experience. And we had a couple of our students bring their parents. They've never really experienced a program like this, so they loved it. But they loved being able to share... how they were proud of their student.

Marly worked at the one participating institution that offered both Spanish and English orientation sessions for families. The open-access institution was intentional about the ways in which families were invited to engage and worked from an assumption that Spanish-speaking families were currently involved and wanted to be in the future. For instance, the marketing materials for the Spanish orientation, written entirely in Spanish, included phrases like "Sea parte de la familia (be part of the family)" and "Comparta con otros padres (share with other families)," suggesting a value of familism, an important concept in the engagement practices of Latina/o families. 
Journal Committed to Social Change on Race and Ethnicity | 2017

Some personnel also expressed their wish to have families remain connected and involved during the college experience. One orientation staff member expressed that families are critical to student success, while another argued that the current parenting model promoted by their institution was exclusive of underrepresented families. Staff members contributed to constructions of positive and deficit images, thus suggesting a tension or dissonance in both individual conceptualizations and institutional structuring of family engagement. The difference between dominant discourse on family engagement in contrast with the shift in both perceptions of families and plans for the future was evident not only at family engagement levels but also in terms of redefining families as valuable partners and key support for student success as opposed to challenges and threats.

\section{Discussion}

The controlling images described in this paper characterize current approaches to family engagement that provide support for the need to critically examine how systems of higher education perpetuate marginalization. Institutional staff must analyze the ways in which they might be perpetuating deficit views of first-generation families, low-income families, and families of color. Institutions must also analyze how the images they create perpetuate notions that frown upon high family involvement and advocate for less participation, arguing this is more beneficial for the development of students (Carney-Hall, 2008; LeMoyne \& Buchanan, 2011; Taub, 2008; Taylor, 2006; Lopez Turley, Desmond, \& Bruch, 2010). Unfortunately, stereotypical notions surrounding family involvement and engagement of low-income families, first-generation families, and families of color have long plagued the K-12 educational system (Kiyama 
Journal Committed to Social Change on Race and Ethnicity | 2017

\& Harper, in press. The result, as Carreón et al. (2005) point out, is that families must grapple with and reassert their cultural identities. We are concerned that postsecondary education has mimicked $\mathrm{K}-12$ in establishing descriptive and limiting ways in which families should be involved and has done so through stereotypical and deficit lenses.

Although most institutions in our sample encouraged some level of parental and family engagement, they established guidelines, thus defining engagement in specific ways. Interestingly, we noted that sometimes all three controlling images appeared within the same institution among different people or contexts within the institution. Negative assumptions continue to be guided by a dominant discourse around what families and students should do to ensure student success in college, which was evident in the ever-absent and malleable family images.

\section{Implications}

Institutions must examine their parent and family engagement models to determine embedded assumptions regarding communication with families about who is involved or invited on campus. The examples of the cornerstone families were found in institutions already committed to examining current programming and developing more inclusive engagement opportunities for families. This is an important first step in a likely multi-step, family co-created programming process that is needed to foster student success. We encourage institutions to not only create inclusive programming, but establish close partnerships with families to facilitate collaborative programming. In doing so, institutions can tap into the cultural assets and wealth that first-generation families, low-income families, and families of color bring to campus. Arzuaga (2016) recommends serving the needs of these populations, in part, through increased 
Journal Committed to Social Change on Race and Ethnicity | 2017

programming such as preorientation sessions that can offer families opportunities to ask questions and build relationships on a smaller scale (in comparison to the oftenoverwhelming experience of orientation). Asset-based models for postsecondary engagement can be adapted from K-12 models such as the Ecologies of Parental Engagement (EPE) (Calabrese Barton, et al., 2004), which emphasizes the families have agency to author their own place and engagement in schools. EPE is particularly useful when considering families from diverse backgrounds whose engagement practices are influenced by cultural resources, relationships with community members, and their own forms of capital (Calabrese Barton, et al., 2004).

Specific practice-based implications include developing culturally-relevant communication systems (e.g., in families' home language) that encourage family engagement in leadership and advisory groups like parent and family associations. These strategies have created some promising practices, particularly in terms of language inclusivity (Coburn \& Woodward, 2001; Price, 2008; Kiyama \& Harper, 2015 and involvement in parent associations (Savage, 2008; Kiyama \& Harper, 2015). Within programs, another strategy would be to incorporate diverse families into orientation programming - such as through parent and family panels - to establish mechanisms by which families from similar backgrounds can relate and connect with one another. Our research with parents and families has revealed the many ways in which families can offer support to other families, which also addresses a common institutional constraint of limited staff and resources (Kiyama, Harper, Ramos, \& Aguayo, 2016. This constraint is also evident in the growing costs and expenses related to orientation (Harper, Kiyama, Aguayo, \& Ramos, 2017), which institutions must consider 
diminishing. That is, create awareness about possible waivers, exceptions, and alternate accommodations. Finally, when developing marketing and assessment tools for programming, ensure that first-generation families, low-income families, and families of color are represented. If orientation is to be welcoming and inclusive, the content of those programs should reflect and value the diversity of today's college student population.

Research in the area of parent and family engagement must also be expanded. While a preponderance of literature on family engagement exists at the K-12 level (see Kiyama \& Harper, 2015, research at the postsecondary level remains scarce and is limited in its representation of the full range of family engagement characteristics, particularly when considering diverse backgrounds. One noteworthy limitation of this paper is that we cannot confirm if the stereotypes and images of engagement that we analyzed from the institutional perspective were experienced realities of the parents and family members themselves. Therefore, future analysis must include the experiences of parents and family members in order to better capture engagement practices. Having both the institutional perspective and family perspective will allow researchers and practitioners to have a more holistic understanding of the ways in which parent and family engagement can influence student success.

\section{Conclusion}

This study examined institutional messaging and responsibility when working to engage first-generation families, low-income families, and families of color. By utilizing controlling images as a framework, we are able to critically examine the stereotypes ascribed to families that often mold their engagement experiences. Further, findings 
Journal Committed to Social Change on Race and Ethnicity | 2017

also demonstrate how these stereotypes can implicitly or explicitly influence the engagement practices of diverse families. We assert that support and engagement from families can offer a crucial element for students' postsecondary success. Thus, these assumptions must be dismantled in order to allow students to capitalize on the cultural support available to them within their families and communities. Institutional staff can examine programming and engagement efforts so that these better reflect and incorporate the voices of all parents and families. 
Journal Committed to Social Change on Race and Ethnicity | 2017

\section{References}

Arzuaga, A. (2016). Family engagement for first-generation families and families of color. In V. Pendakur (Ed.), Closing the opportunity gap: Identity-conscious strategies for retention and student success. Sterling, VA: Stylus.

Auerbach, S. (2004). Engaging Latino parents in supporting college pathways: Lessons from a college access program. Journal of Hispanic Higher Education, 3(2), 125 145.

Berzin, S.C. (2010). Educational aspirations among low-income youths: Examining multiple conceptual models. Children \& Schools, 32(2), 112-124.

Bonilla-Silva, E. (2003). Racism without racists: Color-blind racism and the persistence of racial inequality in the United States. Lanham, MD: Rowman \& Littlefield.

Calabrese Barton, A., Drake, C., Perez, J.G., St. Louis, K., \& George, M. (2004). Ecologies of parental engagement in urban education. Educational Researcher, 33(4), 3-12.

Carney-Hall, K. (2008). Understanding current trends in family involvement. New Directions for Student Services, 122, 3-14.

Carreón, G.P., Drake, C., \& Calabrese Barton, A. (2005). The importance of presence: Immigrant parents' school engagement experiences. American Educational Research Journal, 42(3), 465-498.

Charmaz, K. (2006). Constructing grounded theory: A practical guide through qualitative analysis. Thousand Oaks, CA: Sage Publications.

Choi, J., Tekleselassie, A., \& Mallery, C. (2013). Unpacking the gender gap in postsecondary participation among African Americans and Caucasians using hierarchical generalized linear modeling. The Journal of Negro Education, 82(2), 139-156.

Choy, S.P., Horn, L.J., Nuñez, A-M., Chen, X. (2000). Transition to college: What helps at-risk students and students whose parents did not attend college. New Directions for Institutional Research, 107, 45-63.

Coburn, K. L., \& Woodward, B. (2001). More than punch and cookies: A new look at parent orientation programs. In B. V. Daniel \& B. R. Scott (Eds.), Consumers, adversaries, and partners: Working with the families of undergraduates (pp. 27- 
Journal Committed to Social Change on Race and Ethnicity | 2017

38). New Directions for Student Services: No. 94. San Francisco, CA: JosseyBass.

Collins, P.H. (1990). Black feminist thought: Knowledge, consciousness and the politics of empowerment. New York, NY: Routledge.

Collins, P.H. (2013). On intellectual activism. Philadelphia, PA: Temple University Press.

Creswell, J. W. (2007). Qualitative inquiry \& research design: Choosing among five approaches. Thousand Oaks, CA: Sage Publications.

Furry, A. N. \& Sy, S. R. (2015). The influence of perceived parental expectations and pressures on women's academic achievement during first year of college. Journal of the First-Year Experience \& Students in Transition, 27(1), 49-67.

Garriott, P.O., Love, K.M., Tyler, K.M., Thomas, D.M., Roan-Belle, C.R., \& Brown, C.L. (2010). Testing attachment model of Latina/o college students' psychological adjustment. Hispanic Journal of Behavioral Sciences, 32(1), 104-117.

Harper, C., Kiyama, J.M., Aguayo, D., \& Ramos, D. (2017) Orienting parents and families: A directed content analysis. Unpublished manuscript.

Holcomb-McCoy, C. (2010). Involving low-income parents and parents of color in college readiness activities: An exploratory study. Professional School Counseling, 14(1), 115-124.

Ishimaru, A. M., Torres, K. E., Salvador, J. E., Lott, J., Williams, D. M. C., \& Tran, C. (2016). Reinforcing deficit, journeying toward equity: Cultural brokering in family engagement initiatives. American Educational Research Journal, 53(4), 850-882.

Jun, A. \& Colyar, J. (2002). Parental guidance suggested: Family involvement in college preparation programs. In W. G. Tierney \& L. S. Hagedorn, (Eds.) Increasing access to college: Extending possibilities for all students (pp. 195-216). Albany, NY: State University of New York Press.

Kiyama, J.M. (2010). College aspirations and limitations: The role of educational ideologies and funds of knowledge in Mexican American families. American Educational Research Journal, 47(2), 330-356. 
Journal Committed to Social Change on Race and Ethnicity | 2017

Kiyama, J.M. \& Harper, C. (2015). Parent and Family Engagement in Higher

Education. ASHE Higher Education Report Series. San Francisco, CA: JosseyBass.

Kiyama, J.M. \& Harper, C. (in press). Beyond hovering: A conceptual argument for an inclusive model of family engagement in higher education. The Review of Higher Education.

Kiyama, J.M., Harper, C.E. \& Ramos, D. (invited, in press). First-generation students and their families: Institutional responsibility during college access and transition. In A.C. Rondini, B. Richards-Dowden, \& Nicolas Simon (Eds.) Clearing the Path: Qualitative Studies of the Experience of First-Generation College Students. Lexington Press.

Kiyama, J.M., Harper, C.E., Ramos, D. \& Aguayo, D. (2016). Parents in Transition: A Multiple Case Study of Parent and Family Orientation Programs. A report for participant institutions. Unpublished manuscript.

Kiyama, J.M. \& Harper, C. with Ramos, D., Aguayo, D., Page, L., \& Riester, K. A. (2015). Parent and Family Engagement in Higher Education. ASHE Higher Education Report Series. San Francisco, CA: Jossey-Bass.

Kolkhorst, B.B., Yazedjian, A., \& Toews, M.L. (2010). Students' perceptions of parental support during the college years. College Student Affairs Journal, 29(1), 47-63.

Kwon, K. A., Yoo, G., \& De Gagne, J. C. (2017). Does culture matter? A qualitative inquiry of helicopter parenting in Korean American college students. Journal of Child and Family Studies, 1-12.

LeMoyne, T., \& Buchanan, T. (2011). Does "hovering" matter? Helicopter parenting and its effect on well-being. Sociological Spectrum, 31(4), 399-418.

López Turley, R. N., Desmond, M., \& Bruch, S. K. (2010). Unanticipated educational consequences of a positive parent-child relationship. Journal of Marriage and Family, 72(5), 1377-1390.

Lowe, M. R., Byron, R.A., Ferry, G. \& Garcia, M. (2013). Food for thought: Frequent interracial dining experiences as a predictor of students' racial climate perceptions. Journal of Higher Education, 84(4), 569-600. 
Journal Committed to Social Change on Race and Ethnicity | 2017

McCulloh, E. E. (2016). Parent Support and Retention of Rural First-Generation College Students. Walden University.

Melendez, M.C. \& Melendez, N.B. (2010). The influence of parental attachment on the college adjustment of White, Black, and Latina/Hispanic women: A cross-cultural investigation. Journal of College Student Development, 51(4), 419-435.

Merriam, S. B. (1998). Qualitative Research and Case Study Applications in Education. Revised and Expanded from" Case Study Research in Education." San Francisco; Jossey-Bass Publishers.

McCarron, G.P. \& Inkelas, K.K. (2006). The gap between educational aspirations and attainment for first-generation college students and the role of parental involvement. Journal of College Student Development, 47(5), 534-549.

Parade, S. H., Leerkes, E. M., \& Blankson, A. N. (2010). Attachment to parents, social anxiety, and close relationships of female students over the transition to college. Journal of Youth and Adolescence, 39(2), 127-137.47-60.

Plageman, P. M., \& Sabina, C. (2010). Perceived family influence on undergraduate adult female students. The Journal of Continuing Higher Education, 58(3), 156166.

Price, J. (2008). Using purposeful messages to educate and reassure parents. In K. C. Carney-Hall (Ed.), New Directions for Student Services: No. 122. Managing parent partnerships: Maximizing influence, minimizing interference, and focusing on student success (pp. 29-42). SanFrancisco, CA: Jossey-Bass.

Reed, K., Duncan, J. M., Lucier-Greer, M., Fixelle, C., \& Ferraro, A. J. (2016). Helicopter parenting and emerging adult self-efficacy: Implications for mental and physical health. Journal of Child and Family Studies, 25(10), 3136-3149.

Rostad, W. L., Medina, A. M., \& Hurtig-Crosby, P. (2014). Fathers in the dorm room: The unique influence of fathers and mothers on young adult functioning. Fathering: A Journal of Theory, Research, and Practice about Men as Fathers, 12(1), 3-17.

Sapp, V. T., Kiyama, J. M., \& Dache-Gerbino, A. (2016). Against all odds: Latinas activate agency to secure access to college. NASPA Journal about Women in Higher Education. 9(1), 39-55. 
Journal Committed to Social Change on Race and Ethnicity | 2017

Sarigiani, P. A., Trumbell, J. M., \& Camarena, P. M. (2013). Electronic communications technologies and the transition to college: Links to parent-child attachment and adjustment. Journal of the First-Year Experience \& Students in Transition, 25(1), 35-60.

Savage, M. (2008). Developing, staffing, and assessing parent programs. In K. C. Carney-Hall (Ed.), New Directions for Student Services: No. 122. Diversity and higher education: Theory and impact on educational outcomes (pp. 67-79). San Francisco, CA: Jossey-Bass.

Sax, L.J. \& Wartman, K.L. (2010). Studying the impact of parental involvement and college student development: A review and agenda for research. In J.C. Smart (ed.), Higher Education: Handbook of Theory and Research. No. 25 (pp. 219255). New York, NY: Springer Publishing.

Sax, L.J. \& Weintraub, D.S. (2014). Exploring the parental role in first-year students' well-being: Considerations by gender. Journal of Student Affairs Research and Practice, 51(2), 113-127.

Schofield, J. (2003). The colorblind perspective in school: Causes and consequences. In J.A. Banks \& C.A. McGee-Banks (Eds.), Multicultural education: Issues and perspectives (pp. 247-267). New York, NY: John Wiley \& Sons.

Serido, J., Shim, S., Mishra, A., \& Tang, C. (2010). Financial parenting, financial coping behaviors, and well-being of emerging adults. Family Relations, 59(4), 453-464.

Smith, W., \& Zhang, P. (2010). The impact of key factors on the transition from high school to college among first-and second-generation students. Journal of The First-Year Experience \& Students in Transition, 22(2), 49-70.

Taub, D. J. (2008). Exploring the impact of parental involvement on student development. In K.C. Carney-Hall (Ed.), Diversity and higher education: Theory and impact on educational outcomes, New Directions for Student Services, No. 122, (pp. 15-28). San Francisco, CA: Joseey-Bass.

Taylor, M. (2006). Helicopters, snowplows, and bulldozers: Managing students' parents. The Bulletin, 74(6), np. Retrieved October 4, 2014 from http://www.acui.org/publications/bulletin/article.aspx?issue=304\&id=1842 
Tierney, W.G. (2002). Parents and families in precollege preparation: The lack of connection between research and practice. Educational Policy, 16, 588-606.

Tierney, W.G. \& Auerbach, S. (2004). Toward developing an untapped resource: The role of families in college preparation. In W.G. Tierney, Z.B. Corwin, \& J.E. Colyar (Eds.), Preparing for college: Nine elements of effective outreach (pp. 2948). New York, NY: State University of New York Press.

Ulutas, I., \& Aksoy, A. B.(2014). The impact of helicopter parenting on the social connectedness and anxiety level of university students. International Academic Conference on Social Sciences and Humanities.

Ward-Roof, J. A., Heaton, P. M., \& Coburn, M. B. (2008). Capitalizing on parent and family partnerships through programming. New Directions for Student Services, (122), 43-55.

Wartman, K.L. \& Savage, M.B. (2008). Parental involvement in higher education: Understanding the relationship among students, parents, and the institution. San Francisco, CA: Jossey-Bass.

Yamamura, E. K., Martinez, M. A., \& Saenz, V. B. (2010). Moving beyond high school expectations: Examining stakeholders' responsibility for increasing Latina/o students' college readiness. The High School Journal, 93(3), 126-148. doi: $10.1353 /$ hsj. 0.0045

Yin, R. K. (2013). Case study research: Design and methods. Sage publications.

Yosso, T. J. (2005). Whose culture has capital? A critical race theory discussion of community cultural wealth. Race Ethnicity and Education, 8(1), 69-91. 